\title{
Correction to: The prevalence of hypertension and its distribution by sociodemographic factors in Central Mozambique: a cross sectional study
}

Mika Matsuzaki ${ }^{1 *}$, Kenneth Sherr ${ }^{2,3}$, Orvalho Augusto ${ }^{2,4}$, Yoshito Kawakatsu², Kristjana Ásbjörnsdóttir ${ }^{5}$, Falume Chale ${ }^{6}$, Alfredo Covele ${ }^{3}$, Nelia Manaca ${ }^{3}$, Alberto Muanido ${ }^{3}$, Bradley H. Wagenaar ${ }^{1,2}$, Ana O. Mocumbi ${ }^{7}$, Sarah Gimbel ${ }^{2,8}$ and the InCoMaS Study Team

\section{Correction to: BMC Public Health 20, 1843 (2020) https://doi.org/10.1186/s12889-020-09947-0}

It was highlighted that in the original article [1] some of the authors Given names and Family names were erroneously interchanged. This Correction article shows the correct author names. The original article has been updated.

\begin{abstract}
Author details
'Department of International Health, Johns Hopkins Bloomberg School of Public Health, Baltimore, MD, USA. ${ }^{2}$ Department of Global Health, University of Washington, Seattle, WA, USA. ${ }^{3}$ Health Alliance International, Seattle, WA, USA. ${ }^{4}$ Department of Community Medicine, Eduardo Mondlane University, Maputo, Mozambique. ${ }^{5}$ Department of Epidemiology, University of Washington, Seattle, WA, USA. ${ }^{6} \mathrm{CIOB}$, University of Washington, Seattle, WA, USA. ${ }^{7}$ INS, Maputo, Mozambique. ${ }^{8}$ Department of Family and Child Nursing, University of Washington, Seattle, WA, USA.
\end{abstract}

Published online: 28 December 2020

\section{Reference}

1. Mika, et al. The prevalence of hypertension and its distribution by

sociodemographic factors in Central Mozambique: a cross sectional study. BMC Public Health. 2020;20:1843. https://doi.org/10.1186/s12889-020-09947-0.

The original article can be found online at https://doi.org/10.1186/s12889020-09947-0

*Correspondence: mmatsuz2@jhu.edu

'Department of International Health, Johns Hopkins Bloomberg School of Public Health, Baltimore, MD, USA

Full list of author information is available at the end of the article

(c) The Author(s). 2020 Open Access This article is licensed under a Creative Commons Attribution 4.0 International License, which permits use, sharing, adaptation, distribution and reproduction in any medium or format, as long as you give appropriate credit to the original author(s) and the source, provide a link to the Creative Commons licence, and indicate if changes were made. The images or other third party material in this article are included in the article's Creative Commons licence, unless indicated otherwise in a credit line to the material. If material is not included in the article's Creative Commons licence and your intended use is not permitted by statutory regulation or exceeds the permitted use, you will need to obtain permission directly from the copyright holder. To view a copy of this licence, visit http://creativecommons.org/licenses/by/4.0/ The Creative Commons Public Domain Dedication waiver (http://creativecommons.org/publicdomain/zero/1.0/) applies to the data made available in this article, unless otherwise stated in a credit line to the data. 